\title{
Ferritin and bile acid levels during the intrauterine pre-treatment of gastroschisis by serial amnioexchange
}

\author{
Seri amniotik sıu değişimi ile gastroşizisin intrauterin ön-tedavisinde ferritin ve \\ safra asidi düzeyleri
}

\author{
Namık Demir ${ }^{1}$, Mehmet Tunç Canda ${ }^{1}$, Şamil Kuday², Cengiz Öztürk ${ }^{3}$, Orçun Sezer ${ }^{1}$, Nihal Danaoğlu ${ }^{1}$ \\ ${ }^{1}$ Obstetrics Unit, Kent Hospital, Izmir, Turkey \\ ${ }^{2}$ Pediatric Surgery Unit, Kent Hospital, Izmir, Turkey \\ ${ }^{3}$ Veonatology Unit, Kent Hospital, Izmir, Turkey
}

\section{Abstract}

We present a case of gastroschisis managed with serial amnioexchanges. Marked decreases were detected in both ferritin and bile acid levels following the procedure. The bowels were not severely affected, as expected. After delivery, single primary closure of the defect was performed. Early enteral feeding and shorter hospital stay were the main outcome measures. Intrauterine pre-treatment of gastroschisis by serial amnioexchange may provide benefits by decreasing the levels of inflammatory products in the amniotic fluid in order to lower the possible risk of bowel damage, and this may help to achieve better surgical and postnatal outcomes.

(J Turkish-German Gynecol Assoc 2013; 14: 53-5)

Key words: Gastroschisis, amnioexchange, ferritin, bile acid, intrauterine treatment

Received: 22 July, 2011

Accepted: 20 September, 2012

\section{Ozet}

Seri amniotik sıvı değişimleri ile yönetilen bir gastroşizis olgusu sunduk. İşlem sonrası ferritin ve safra asidi düzeylerinde belirgin azalmalar saptandı. Bağırsaklar beklenildiği kadar çok etkilenmemişti. Doğumdan sonra, defektin tek primer kapatılması uygulandı. Ana ölçütler, erken enteral beslenme ve daha kısa hastanede kalış süresiydi. Seri amniotik sıvı değişimi ile gastroşizisin intrauterin ön-tedavisi amnion sıvısındaki enflamasyon ürünlerini azaltarak olası bağırsak hasarı riskini azaltarak yarar sağlayabilir ve bu daha iyi cerrahi ve doğum sonrası sonuçlara ulaşmak için yardımcı olabilir.

(J Turkish-German Gynecol Assoc 2013; 14: 53-5)

Anahtar kelimeler: Gastroşizis, amniotik sıvı değişimi, ferritin, safra asidi, intrauterin tedavi

Geliş Tarihi: 22 Temmuz 2011

Kabul Tarihi: 20 Eylül 2012

\section{Introduction}

Gastroschisis is a congenital anomaly, in which the fetal intestines herniate through a paraumbilical (usually right sided) full thickness abdominal wall defect without any covering membrane (1). The direct interaction of intestines with the amniotic fluid leads to an inflammatory reaction due to the amount of intestinal waste products, inflammatory mediators or both. The effect of inflammation on the bowel serosa, denoted as "perivisceritis", results in the formation of a fibrous peel and intestinal edema after 30 gestational weeks (2).

Previously, it has been shown that repeated amniotic fluid exchange procedures may help to reduce the concentration of inflammatory products that could damage the intestines (3). The aim of this report is to show that repeated amniotic fluid exchange may help to lower the effect of a negative impact of gastrointestinal products, including amniotic fluid ferritin and bile acids, on the intestines and may help to slow the development of a less fibrous peel surrounding the intestines at birth.

\section{Case Report}

A 24 year-old primigravida was detected with a right-sided paraumbilical defect with protruding intestines at 14 weeks of her pregnancy (Figure 1). The case was diagnosed as an isolated gastroschisis. Amniocentesis was performed at 19 gestational weeks and a male fetus with a normal karyotype was detected. The parents were informed about the amnioexchange procedure; they opted to undergo the technique and provided their informed consent. The local ethics committee approved the procedure. The technique used for the amnioexchange procedure was that previously described by Aktug et al. (4). Serial amnioexchange procedures were performed every four weeks until birth, starting at 24 gestational weeks. Overall, a total of four procedures were performed. The total amnioexchange volume was determined empirically and according to previous reports (4). Amniotic fluid volume (AFV) was restored to normal levels of $11-13 \mathrm{~cm}$ 
if oligohydroamnios was present. A single dose of antibiotic prophylaxis was administered before each procedure. There was no need for hospitalization or tocolytic therapy. Amniotic fluid samples were assayed for ferritin and bile acids. Table 1 summarizes the amount of fluid, ferritin and bile acid levels before and after pre-treatment and fetal intestinal diameters and wall thicknesses at the time of the procedure.

A caesarean section was performed at 37 weeks gestation due to late decelerations. A male infant of $2870 \mathrm{~g}$ with Apgar scores of 8 at $1 \mathrm{~min}$ and 10 at $5 \mathrm{~min}$ was delivered. There were small and large bowel loops protruding through the paraumbilical defect with little fibrous peel or edema (Figure 2). Intestines were separated easily and placed into the abdomen; primary closure of the defect was performed immediately after birth. Oral feeding was started at postoperative day 5; at postoperative day 7 oral feeding was cancelled due to some vomiting and restarted at postoperative day 13. The patient was discharged on the $20^{\text {th }}$ postoperative day. After 1 year of follow-up, the baby was normal.

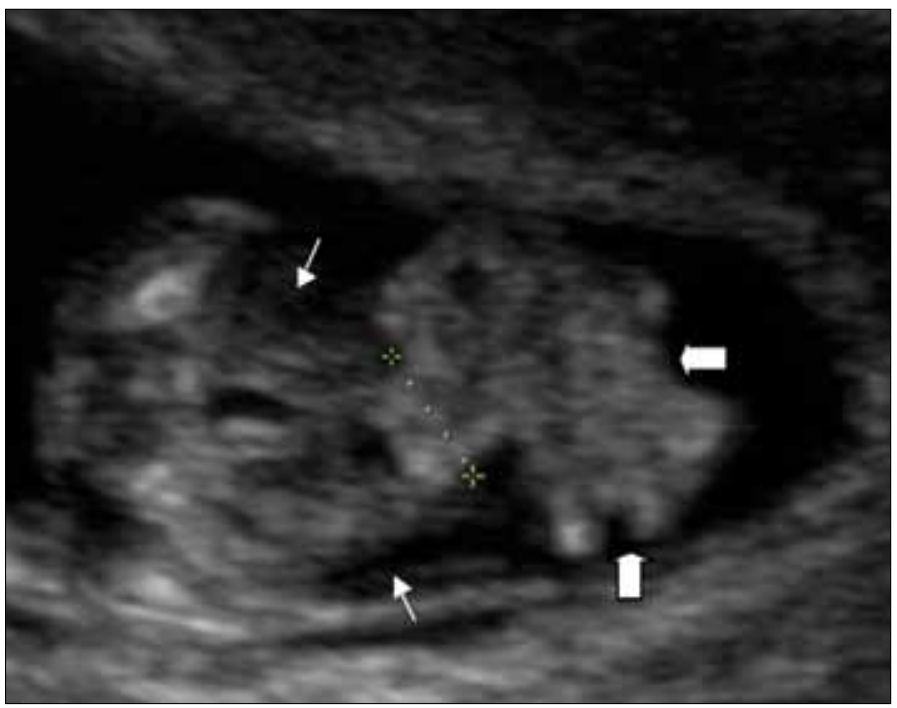

Figure 1. Thin arrows indicate the abdomen of $14^{\text {th }}$ week fetus. Thick arrows indicate the protruding fetal intestines. Two plus signs indicate the distance of the paraumbilical defect

\section{Discussion}

Fetuses with gastroschisis will suffer from complications mostly associated with intestinal damage due to direct contact with inflammatory products in the amniotic fluid (5). This inflammation is supposed to cause bowel edema and induce the creation of fibrous peel, which may lead to intestinal atresia, malrotation, intestinal wall thickening, hypoperistaltism, and necrotising enterocolitis (1). All of these issues may cause difficulties in primary closure, increased length of stay in the neonatal intensive care unit, lower tolerance of enteral feeding and prolonged hospital stay.

Perivisceritis of the intestines was expected to occur due to inflammatory mediators and intestinal products (interleukin 8, matrix metalloproteinases, protein, ferritin, amino acids, $\gamma$-glutamyl transferase, amylase, lipase and meconium staining of the liquor) only after 30 weeks' gestation $(2,6)$. However, it was previously shown that ferritin levels were higher in the second trimester than the third trimester (3). Therefore, in this case we started the first exchange procedure at 24 gestational weeks. In this way, we aimed to reduce the possible risk of early development of intestinal damage. This implication should be

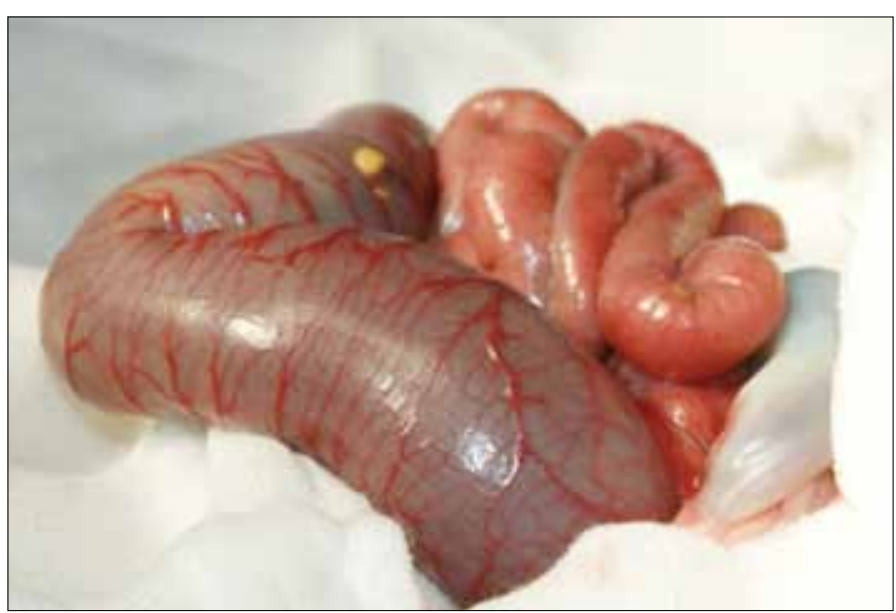

Figure 2. The intestines were seen, immediately after the birth and before the primary closure surgery. It is seen that, the small and large bowels were almost in normal appearance

Table 1. Exchange, infusion and amniotic fluid volume, ferritin and bile acid levels and fetal intestinal measurements before, after or at the time of the procedure

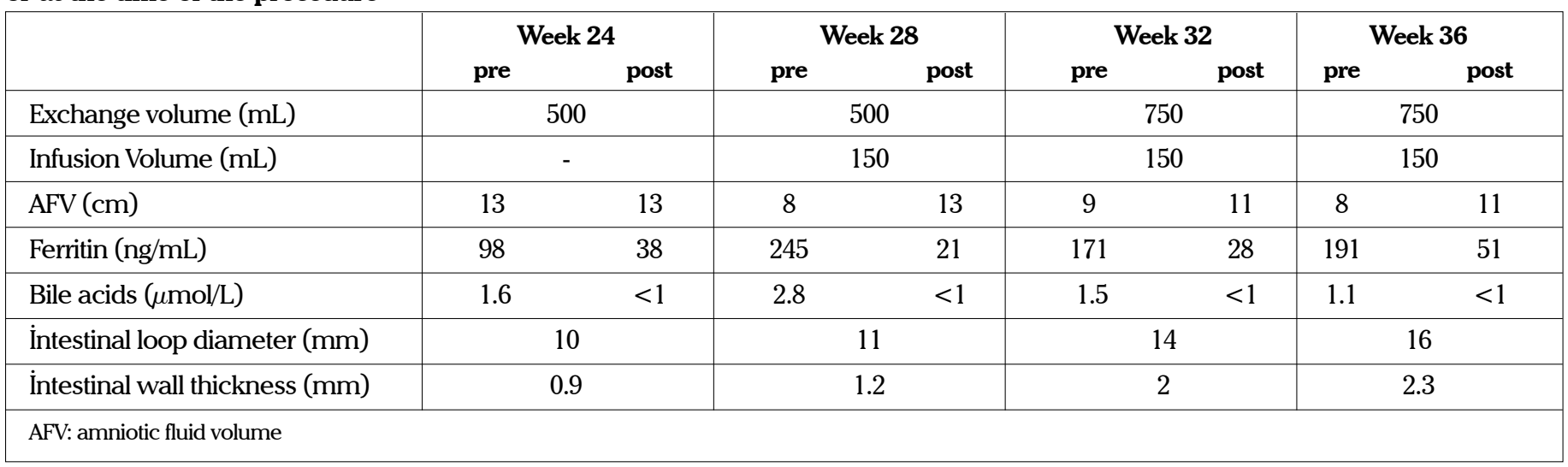


confirmed with case series or randomized controlled trials. Bile acids, which might directly disrupt intestinal function and/ or might increase the inflammatory reaction in the amniotic fluid, were also studied (7). In the present study, ferritin and bile acid levels peaked at 28 gestational weeks. Additionally, bile acid levels were as high at 24 gestational weeks as they were at $32^{\text {nd }}$ gestational week. There were marked decreases in both ferritin and bile acid levels following the amnioexchange procedure.

It was previously reported that mean hospital stay for gastroschisis patients was 41 days (8). The amnioexchange procedure reduced the hospital stay time almost by half in the present study. Additionally, in term deliveries of fetuses with gastroschisis, the mean time to achieve enteral feeding was 17 days (9). In our study, the amnioexchange procedure seemed to reduce this value.

Previously, Midrio et al. (7) reported that the amnioexchange procedure did not have much benefit in gastroschisis. In that study, a total of 8 gastroschisis cases were evaluated. In some cases, they only performed amnioinfusion without amnioexchange. Their study did not include a control group. Additionally, most of their concerns were related to infection and preterm premature rupture of membranes caused by the invasive procedure. However, it was previously reported that the amnioexchange procedure did not have any side effects in humans (10).

Although our case might be important in order to give an idea about serum ferritin and bile acid levels during the intrauterine pre-treatment of gastroschisis by serial amnioexchange, a single case report might not be adequate to sustain our conclusions. Therefore, large clinical randomized controlled trials are necessary to make definite conclusions regarding on the pros and cons of the amnioexchange procedure in gastroschisis.

\section{Conflict of interest}

No conflict of interest was declared by the authors.

\section{References}

1. Fillingham A, Rankin J. Prevalence, prenatal diagnosis and survival of gastroschisis. Prenat Diagn 2008; 28: 1232-7. [CrossRef]

2. Tibboel D, Vermey-Keers C, Kluck P, Gaillard JL, Koppenberg J, Molenaar JC. The natural history of gastroschisis during fetal life: development of the fibrous coating on the bowel loops. Teratology 1986; 33: 267-72. [CrossRef]

3. Burc L, Volumenie JL, de Lagausie P, Guibourdenche J, Oury JF, Vuillard E, et al. Amniotic fluid inflammatory proteins and digestive compounds profile in fetuses with gastroschisis undergoing amnioexchange. BJOG 2004; 111: 292-7. [CrossRef]

4. Aktuğ T, Demir N, Akgür FM, Olguner M. Pretreatment of gastroschisis with transabdominal amniotic fluid exchange. Obstet Gynecol 1998; 91: 821-3. [CrossRef]

5. Fratelli N, Papageorghiou AT, Bhide A, Sharma A, Okoye B, Thilaganathan B. Outcome of antenatally diagnosed abdominal wall defects. Ultrasound Obstet Gynecol 2007; 30: 266-70. [CrossRef]

6. TibboelD, Raine P, McNee M,Azmy A, KlückP, Young D, etal. Developmental aspects of gastroschisis. J Pediatr Surg 1986; 21: 865-9. [CrossRef]

7. Midrio P, Stefanutti G, Mussap M, D’Antona D, Zolpi E, Gamba P. Amnioexchange for fetuses with gastroschisis: is it effective? J Pediatr Surg 2007; 42: 777-82. [CrossRef]

8. Centers for Disease Control and Prevention (CDC). Hospital stays, hospital charges, and in-hospital deaths among infants with selected birth defects--United States, 2003. MMWR Morb Mortal Wkly Rep 2007; 56: 25-9.

9. Soares H, Silva A, Rocha G, Pissarra S, Correia-Pinto J, Guimarães H. Gastroschisis: preterm or term delivery? Clinics (Sao Paulo) 2010; 65: 139-42. [CrossRef]

10. Luton D, de Lagausie P, Guibourdenche J, Oury J, Sibony O, Vuillard E, et al. Effect of amnioinfusion on the outcome of prenatally diagnosed gastroschisis. Fetal Diagn Ther 1999; 14: 152-5. [CrossRef] 